\title{
Challenges and Opportunities for Teaching Practical Skills at Higher Education Institutions under the conditions of COVID- 19 Pandemic
}

Tea Kasradze

Ph.D. in Economics, Professor of CIU, Head of BA Ph.D. Program

Ekaterine Gulua

Ph.D. in Economics, Founder \&CEO of HPML, Assistant-Professor of TSU

\section{Abstract}

The lack of practical skills of graduates of higher education institutions is one of the main challenges of the modern education system of Georgia, which has become even more urgent in the face of the COVID -19 pandemic. Within the framework of the research, we studied the latest scientific literature, researches and reports of various state and international organizations on the experience and current state of practical skills' teaching in Georgia; on the new requirements for the workforce under the pandemic and post-pandemic; and on the future directions of providing students with practical knowledge. The paper also presents an analysis of the results of our research on the attitude of students towards the internship and the approaches of higher education institutions in the evaluation of practical knowledge and skills acquired by the students within the framework of the educational program. Based on the best practice and challenges identified as a result of the research, we have developed appropriate recommendations that we think will facilitate the production of professional graduates equipped with practical skills.

Keywords: quality of education, development of practical skills, internship, employment, knowledge triangle

\section{Introduction}

A well-functioning education system able to provide a competitive workforce for the labor market equipped with practical skills is an important precondition for solving economic problems, social inequality, and reducing misbalances between countries. It is gaining momentum in the face of the COVID19 pandemic - an unprecedented global challenge (European Union, 2015). On the one hand, it ensures the successful operation of economic entities (Chatzkel, J L; 2004), and on the other hand, it has a social function - the development of human capital helps to solve social problems 
(Baron, Angela; Armstrong, Michael; 2013). The education system plays an important role in shaping the supply of quality human resources, which has a positive impact on the country's economic growth and development (Gulua, Ekaterine, 2013). Education affects not only the success of a particular person but also the economy of the country as a whole. Education contributes to the growth of labor productivity. An educated individual is more likely to master advanced technologies, so they are more productive (Boxall, P; Purcell, J; Wright, P, 2007), (Nelson, R R; Phelps, E S, 1966). Education can increase the potential of innovation, create new knowledge, new technologies that contribute to economic growth.

In many types of research of international organizations, we read that education in Georgia is formal, the real qualification level of the workforce does not meet the existing requirements. The low rating of Georgia (93rd place) indicates an incompatibility between qualifications and job requirements, in the section of the Higher Education and Retraining Section of Global Competitiveness Index of World Economic Forum (Kasradze, Tea; Antia, Vakhtang; Gulua, Ekaterine, 2019). According to the skillset of graduates, Georgia is in the 123rd place, according to digital skills among the population it is in 101st place, according to the ease of finding skilled employees it is on the 111th position, according to the critical thinking teaching, it is in the 92nd place, according to the diversity of workforce it is in the 116th place (Schwab, Klaus; Martín, Xavier Sala-i; Samans, Richard; 2017-2018).

According to the Global Talent Competitiveness Index, Georgia is in the 76th place out of 119 countries in 2019, 4 places down compared to 2018, it was in the 72nd place, according to the Talent Involvement it is in the 52nd place, on the 92nd position in terms of attracting talents, according to the growth of talents it is in the 107th place, in terms of maintaining talents it is in the 61st place, according to talents with Vocational and Technical Skills (or VT skills) it is in the 80th place and according to Global Knowledge Skills (or GK skills), it is in the 56th place. According to the detailed data from the same index, Georgia is in 60th place based on higher education; According to the expenses incurred on higher education - in 93rd place (Lanvin, Bruno; Monteiro, Felipe; 2019). The same is shown by the low rating of Georgia (87th position among 137 countries, 4.0 points from maximum 7 points) in the section of Higher Education and Training of Global Competitiveness Index of 2017-2018 World Economic Forum (Lezava, Diana; Amashukeli, Mariam, 2015).

This situation is reflected in the employment level (Kasradze, Tea, 2013). One of the main reasons for a high level of employment is that human resource qualification often fails to meet market demands. $61 \%$ of the unemployed in Georgia have higher than secondary school education (vocational or higher) and fall into the category of middle or high-skilled workers. $31 \%$ of the unemployed are educated with the modern Bologna system, which indicates shortcomings in the existing higher education system and incompatibility of received qualification in this system with job requirements (Lezava, Diana; Amashukeli, Mariam, 2015). 
It is exactly this latter challenge that is explored in the present paper. The research aimed to find out to what extent graduates of higher education institutions are equipped with practical skills appropriate to the demands of the labor market and the challenge of the 21st century.

In particular, we studied the challenges of equipping business administration education program graduates at higher education institutions of Georgia with practical skills relevant to the requirements of the labor market and based on the findings developed recommendations.

Here we want to emphasize that in this paper we do not try to ignore the importance of theoretical knowledge. Moreover, we believe that practice cannot exist without theory, or to put a more normative spin on it, it should not exist without theory. To attempt to undertake practice without theory in effect means that we will not be able to learn from past experiences, we will not gain insights from our previous failures and successes, nor will we be able to project into the future to anticipate possible outcomes. In stressing the integrative relationship between theory and practice, rather than the gap between them, our hope is that theory, or the ability to theorize, i.e. 'to do theory', will come to be seen as the practical skill that it truly is (Leaf, 2013).

\section{Review of Literature, Researches, and Reports of State and International Organizations}

A literature review has shown that the lack of practical skills of graduates of higher education programs and/or non-compliance with the requirements of the labor market is a problematic issue of the education systems of both developing and developed countries. In developing countries, higher education institutions mostly use traditional teaching methods, which do not allow students to develop the competencies required by the labor market. The main reason is that the developed curricula are not adequately based on the combination of knowledge and skills. Also, another big challenge is that curriculum developers are sometimes incompetent. Most are at the academic level and have little or no idea of the actual requirements of the Labor Market. Besides, other challenges are facing higher education institutions, such as inadequate teaching and learning opportunities and resources, insufficient funding of the academic program, weak links between industry and education, lack of competent teachers, etc. which also affects learning outcomes (Chen, 2017).

In developed countries, we find numerous reports where the focus is on raising employment opportunities in academic courses. While the majority of the higher education institutions of developed countries are making adequate efforts to develop their students' employability skills researchers report that graduates do not have the adequate skills needed for the labor market (Ugochukwu Chinonso Okolie, 2019). The research conducted by the Confederation of British Industry (CBI) reviled that in the UK the employers were experiencing problems filling jobs with appropriately skilled graduates. Well over half of all firms participating in the research fear that there will 
not be enough people available with the skills needed to fill their high-skilled jobs (CBI, 2017).

In 2020, at the World Economic Forum in Davos (Bruce-Lockhart, 2020) it was announced that the role of technology at the workplace will be increased in the future. If in 2018 the share of technology was 29\%, by 2025 it will increase up to $52 \%$. From human skills along with mathematics, computing, and data analysis - creativity, critical thinking, persuasion, and negotiation will become relevant; Attitudes between employer and employee are changing; At the same time, the challenges of COVID 19 require not only the reorganization of the learning process but also the adaptation of the programs themselves, so that in these new conditions of teaching students can develop the necessary skills for the future.

Improving business training programs is important to adapt to the challenges facing the business to provide the business sector with a qualified workforce. It is difficult to predict exactly what trends will emerge in the future, but it will become more and more digital (Beardwell, J; Thomson, A, 2017). The technique will completely replace people's technical skills and make the following human skills actual: complex problem solving, critical thinking, creativity, people management, coordinating with others, emotional intelligence, judgment and decision making, service orientation, negotiation, cognitive flexibility (Gray, 2016).

As noted in the Lisbon Declaration, today as never before, rethinking the education system is important, collaborating between businesses and higher education institutions should rise to new heights, and solid mechanisms for mutual accountability should be established (The Lisbon Declaration, 2007).

Creating a quality education system is possible based on concerted efforts of three entities - Higher education institutions, Business sector and Government (Zarnadze \& Kasradze, 2019).

Higher educational institutions have the main responsibility for providing useful, modern knowledge to students (Gulua, Ekaterine, 2018). The main reason for the problems in terms of transferring practical knowledge is that today the establishment of business management specialists at universities is taking place in university buildings and has no close connection with corporate practice. Often the structure of the curriculum is unsubstantiated, theoretical courses are more than practical ones, and textbooks that are used for teaching courses are mostly theoretical and offer virtually nothing to the student in practical teaching (Kasradze, Tea; Zarnadze, Nino, 2018).

Unfortunately, often the lecturers themselves have a lack of practical experience, which affects the results of practical teaching. Although lecturers often have higher education with the appropriate qualifications, they do not have practical experience of working and managing enterprises and companies. The fact that the theoretical 
material to be studied is largely unrelated to practice is an obvious problem for business administration education programs.

Unfortunately, there are no set standards for assessing students' practical skills, and the development of their assessment criteria depends entirely on the lecturer. Assessment criteria for course syllabi often include evaluation of attendance, midterm and final exams (which are mostly theoretical), reports/presentations, case reviews/assignments, and other activities and fails to determine whether students have achieved the expected goals even with the few practical components used in the teaching process, they have improved their practical skills or not (Qualifications Frameworks (Comparative Analysis of International and National Frameworks)).

The qualitative analysis showed that business administration education programs in Georgia, in most cases, provide a training/professional practice course (usually at the graduation stage of the program), although often it is formal. The teaching/professional practice should aim to support a student to transfer the theoretical knowledge acquired within the program of the university in the real activity and to develop and deepen the practical skills. The internship should be focused on revealing the student's creativity, innovative thinking, talent. Unfortunately, the duration of the internship and improperly selected units of the internship will not ensure the achievement of its objectives. At the units of internship, a mentor is assigned to students who have to assess the student's practical skills, although this assessment is often formal and is mainly based on the time physically spent by the student on the place of internship. The internship does not fully reveal the potential of the student. Unfortunately, here too we do not have well-defined assessment criteria that measure how well the desired effect of practical training has been achieved.

It should also be noted that the appointment of an internship supervisor for a student by a university is also formal and supervisors often do not have experience in corporate activities, practical teaching, and leadership skills. The lack of practical experience of university teachers, and often non-existence of it, make it difficult to improve the quality of internship and achieve goals.

It is difficult to develop practical skills effectively without adequate financial support from a higher education institution (Gulua, Ekaterine, 2019). Since universities do not have the appropriate software and they lack computer equipment, unfortunately, in most cases, practical courses such as Financial Management, Financial Analysis, Financial and Management Accounting, etc. are often only theoretically taught. Also in most cases for universities, suitable software is not available for such courses as Project Management, Human Resource Management, Accounting, etc.

Having such software would be especially helpful for HEI during the COVID-19 pandemic when a student fails to come to the unit of internship and carry out practical activities. The pandemic further complicates the development of the student's 
practical skills and makes the achievement of the goals of business administration educational programs doubtable.

Many universities are trying to strengthen practical components, they have created special Experimental Centers/Business Incubators on the spot and are refining the training courses by incorporating practical components into them. However, all this is not systemic and, unfortunately, represents an exceptional case.

\section{Research Design and Findings}

We became interested in the attitudes of students towards an internship at higher education institutions. The survey (with closed questions) was conducted in the spring of 2019 under the auspices of TSU Human Potential Management Laboratory. 614 students of the Faculty of Economics and Business were surveyed. A similar study was conducted in 2017, at first only at TSU (Gulua, Ekaterine, 2017), and then the subject of research became a private university. (Gulua, E.; Kasradze, T.; Zarnadze, N., 2020).

Focus-group Methodology was used to interview the students. Closed-ended (multiple choice questions) and open-ended questions were included in the questionnaire. We studied students' attitude to the learning process, programs, professors' skills, and level of students' trust in the university, whether they believe that they will get modern knowledge and practical skills and will be able to engage in the global competition after graduating from the university without additional practice and training.

Students' attitudes, confidence in the learning process, curricula, and professors' qualifications significantly determine their level of motivation, self-confidence, and learning effectiveness.

The survey showed that $17 \%$ of the respondents are satisfied, believing that they are gaining knowledge at the university that he/she will use in practice, or is already using. The majority - 58\% - are partially satisfied, $24 \%$ are dissatisfied and think they are gaining knowledge that is useless (Diagram 1). 


\section{Diagram 1. Do you think you are getting the knowledge that you can use or are already using in practice?}

- Valid Percent

Avoid to answering the question

No, it is basically useless

Yes, partly

Yes, I'm satisfied
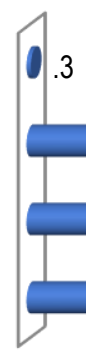

To the question - Do you think that the university where you study has authority among employers? - 73\% of the respondents answered "yes" and "mostly yes". 21\% answered that their university is authoritative for only a small part of the employers, $6 \%$ gave a negative answer to this question (Diagram 2 ).

\section{Diagram 2. Do you think you are studying at a university that enjoys authority among employers?}

- Valid Percent

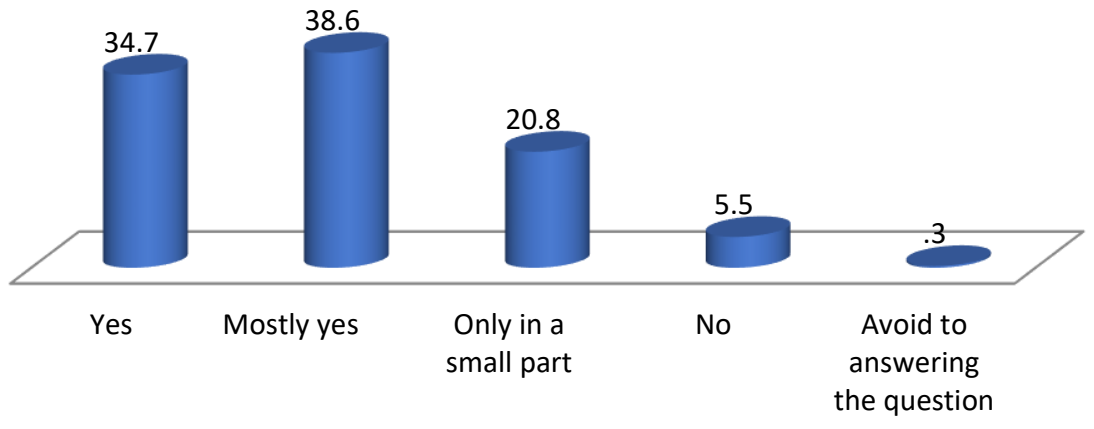

The majority - 55\% - believe that after graduation they will have only theoretical knowledge. $27 \%$ believe that they will be able to get modern knowledge at the university, $17 \%$ are negative (See Diagram 3). 


\section{Diagram 3. Do you think you will have the proper knowledge when you finish your studies? \\ - Valid Percent}

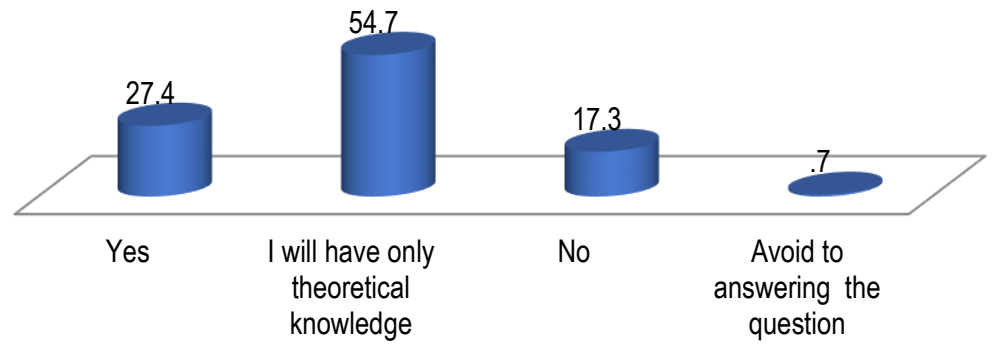

We examined whether students believe they are acquiring globally competitive knowledge or not. $34 \%$ are convinced of this, $47 \%$ are not sure, and $19 \%$ are skeptical (See Diagram 4).

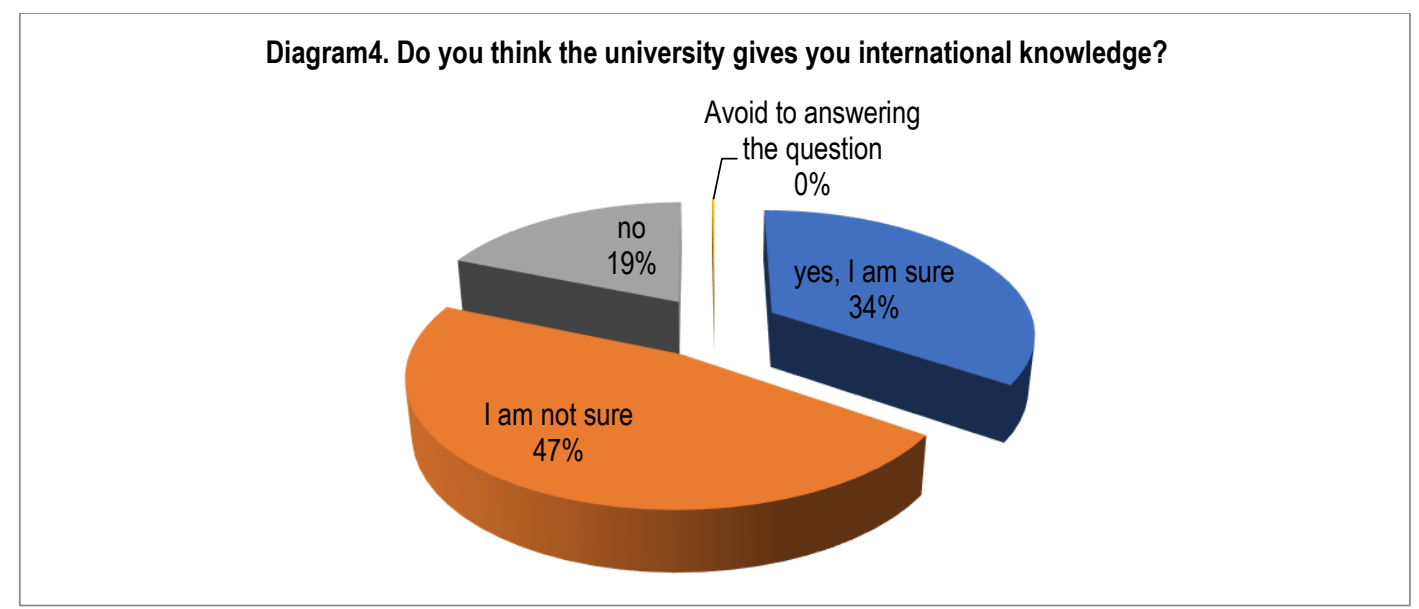

While clarifying the question, the majority of students - $60 \%$ - stated that they only receive international knowledge only in certain subjects; $28 \%$ believe that most subjects provide international knowledge; $6 \%$ are satisfied with all subjects; Also 6\% are dissatisfied with all subjects (Diagram 5). 
Diagaram 5. Are there subjects in which you acquire international knowledge?

- Valid Percent

Avoid to answering the question

Not in any subject

Only in some subjects

In most subjects

Yes, in all subjects

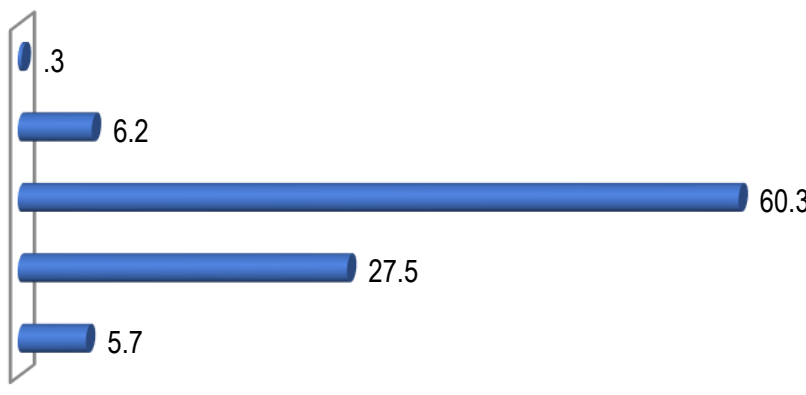

We were also interested in the degree of trust towards lecturers. $68 \%$ of the respondents are satisfied with the lecturers; $21 \%$ like only some lecturers, $2 \%$ expressed a negative attitude (Diagram 6).

\section{Diagram 6. Do you think that lecturers who teach/ taught you are highly qualified? \\ - Valid Percent}

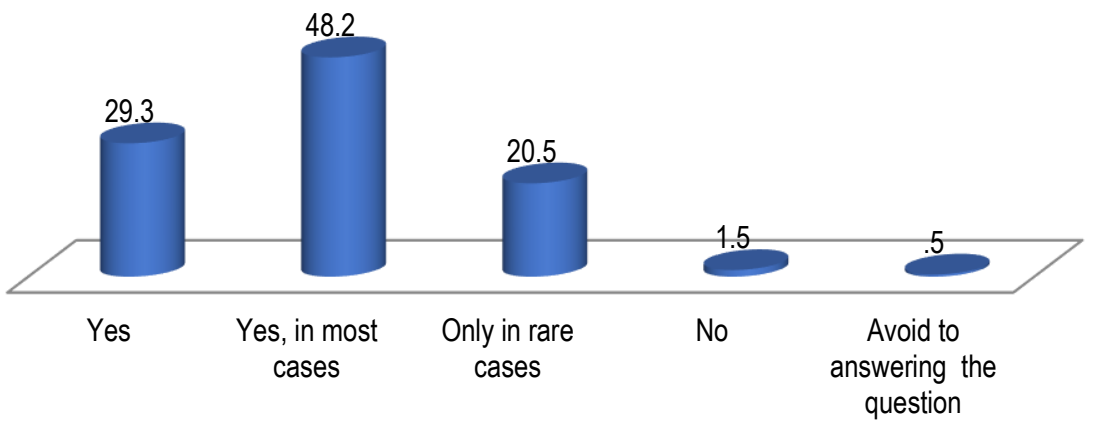

Since students in Georgia have the right to choose their lecturers, we were interested depending on what criteria they make their choice. In this case, a student had the opportunity to select several answers. The number of cases was 725 . The majority $52 \%$ - choose based on professionalism and competence. $36 \%$ prefer lecturers who are loyal to students, $6 \%$ find it difficult to make a choice, $27 \%$ have not an opportunity to choose because of the bases (Diagram 7). 


\section{Diagram 7. What criteria do you use when choosing a lecturer?}

- Percent of Cases $\Sigma=121.3 \%$

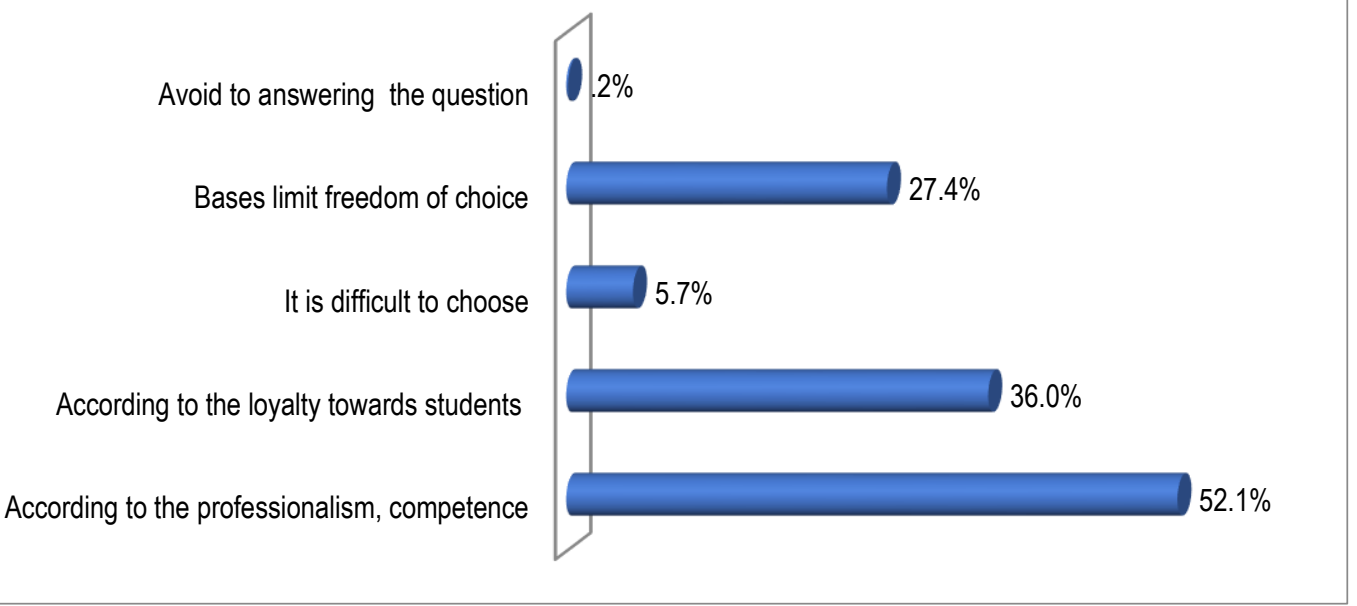

International events, exchange programs allow students to acquire useful skills. We were interested in how students evaluate the care of the university to inform them about these projects. $20 \%$ gave this effort unequivocally positive - high rating, $49 \%$ rated it average, $30 \%$ are negative - th rated it low (Diagram 8).

\section{Diagram 8. Degree of student awareness (about exchange programs, events, etc.)}

- Valid Percent

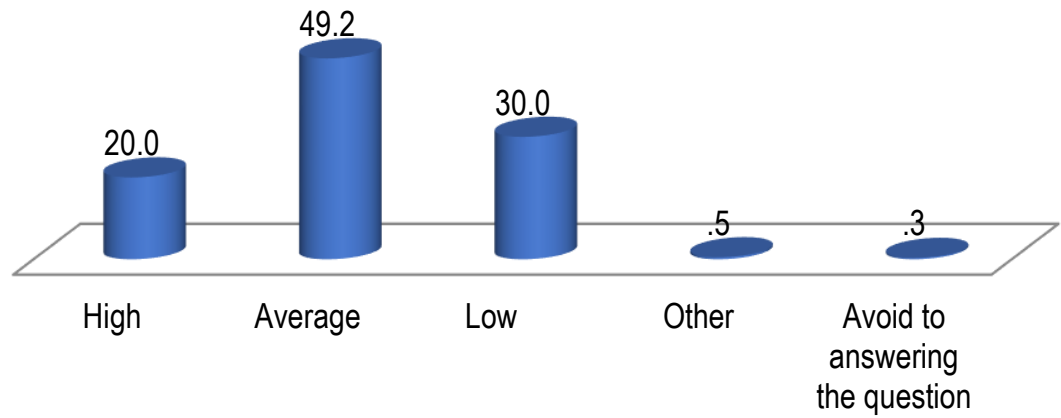

We were interested in how much the students think that it is possible to get better knowledge at other universities of Georgia. 34\% believe that the level of education in Georgia is the same everywhere. $32 \%$ believe that it is possible to acquire better knowledge at other universities, $30 \%$ are satisfied with their university (Diagram 9). 


\section{Diagram 9. Do you think it is possible to get better quality knowledge in other higher education institutions of Georgia?}

- Percent

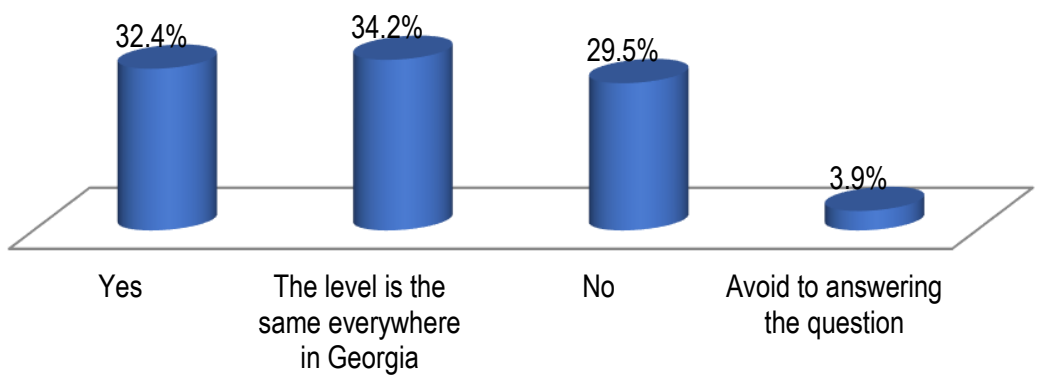

Based on determining the meaning of the Chi-square, the connection between all these variables $(1,2,7,8,9,11,30)$ is less than 0,05 , so the connection is reliable (see Table1).

Table1. Chi-Square Tests

\begin{tabular}{|l|l|l|l|}
\hline & Value & df & $\begin{array}{l}\text { Asymp. Sig. (2- } \\
\text { sided) }\end{array}$ \\
\hline Pearson Chi-Square & $152.410^{\mathrm{a}}$ & 9 & .000 \\
Likelihood Ratio & 156.918 & 9 & .000 \\
Linear-by-Linear Association & .003 & 1 & .957 \\
N of Valid Cases & 614 & & \\
\hline
\end{tabular}

a. 7 cells (43.8\%) have an expected count less than 5 . The minimum expected count is .00.

The business Sector is an important stakeholder of higher education institutions. Employers of business administration program graduates often say that they find it difficult to hire suitable professionals for business management (Gulua, Ekaterine, 2020). They indicate a lack of practical skills for graduates. They note that program graduates have theoretical knowledge, but without additional training, they find it difficult to apply this knowledge in practice. They also have a lack of communication skills and know a foreign language poorly (Kasradze, Tea; Zarnadze, Nino, 2018). With only theoretical training, it is impossible to train business administration specialists adapted to market demands. Students should not only have a deep knowledge of economics and management theory, but should also have practical skills such as adapting to a corporate environment, independent thinking and analytical skills, and more. A modern business needs specialists with management, marketing, decision analysis, and business research skills (Liu, Xiu; Chang, Shangxin, 2020).

In all countries, the business sector wants their potential employees (university graduates) to have such skills as goal setting, delegation skills, communication and 
negotiation skills, strategic planning, leadership skills, team working and teambuilding skills, networking, analytical skills, customer service, sales and marketing skills, general management skills, cash flow management skills, financial management skills, time management skills, project management and planning, problem-solving, digital skills.

The Government of Georgia realizes the role of education in the development of the country, its attitude was reflected in the law in 2019, in particular, according to the Budget Code of Georgia "It is imperative that the draft of the state budget to be prepared and approved in such a way that, according to the functional classification of the Georgian consolidated budget, the amount of funding in the field of education is not less than $6 \%$ of the nominal gross domestic product projected for the year." Before the enactment of this law, funding for education was increasing from year to year, which included not only funding for teaching but also funding for students' and pupils' support services and research (Kasradze, 2018), although it is clear that increasing funding alone is not enough. To improve the employment rate and improve the welfare of society, the quality of knowledge of the graduates of higher education institutions must comply with modern requirements (Kasradze, Tea; Zarnadze, Nino, 2019). It is necessary to monitor the spending and efficiency of the investments made and to introduce mechanisms to ensure fundamental qualitative changes and reforms in this field (ESPAS, 2015).

Based on the qualitative analysis, it became clear that it is necessary for universities to take responsibility for the transfer of quality, useful knowledge to both the state and the business sector, as well as to students, and to establish a mechanism for developing this responsibility. In this case, we can confidently rely on the experience of European universities, including: "Responsible Partnering Guidelines" recommended by the Lisbon Declaration of Collaboration between Universities and Entrepreneurial Organizations (The Lisbon Declaration, 2007), (European University Association).

\section{Summary and recommendations}

Based on the analysis of the article, it has been revealed that there is a problem of a lack of practical skills of business administration education program graduates at higher education institutions in Georgia, which harms their employment rate on the market.

The new digital age needs a graduate armed with practical skills who will be able to keep up with market demands. Therefore, HEIs should pay close attention to practical teaching, giving students the knowledge and practical skills that will be useful in real life.

Higher education institutions need to develop high-quality innovative educational programs with balanced teaching of theory and practical skills. It is important to foster student's learning and integration of theoretical knowledge in practice 
during tertiary education. The researches show that the students should be able to develop their practical skills during the theoretical studies as well because the practice period university offers to them is short for adequate development of practical skills. This problem became even more acute during the Covid-19 pandemic. Cessation of face-to-face teaching has jeopardized the development of students' practical skills, as it is not possible to teach subjects in an adequate format which include the development of professional competencies through practice (clinics, pedagogical residencies, design careers, engineering, science, and generally all those heavily dependent on practical workshops, laboratory work or institutional practices) (UNESCO, 2020). It is difficult to replace these types of courses with online teaching, but universities should create/use online learning platforms that allow them to integrate special e-learning programs (eg e-banking, accounting software, etc.) and conduct practical training. However, this is associated with additional costs, which is generally a problematic issue for private higher education institutions, especially painful in terms of Covid-19.

Not only in Covid-19 pandemic conditions but also in the post-pandemic period HEIs need to pay close attention to the proper selection of teaching methods. Properly selected teaching methods to ensure the development of skills that are very important for the competitiveness of the graduates of a particular program on the market, as well as for the field as a whole.

Universities should engage professionals with practical experience in the field, along with academically qualified theorist teachers; to invite relevant experts, professors, entrepreneurs, experienced management staff and create practical, professional textbooks for business management; to select units of internship more seriously and monitor the progress of internship regularly.

\section{Bibliography}

[1] Baron, Angela; Armstrong, Michael;. (2013). Human Capital Management: Achieving Added Value Through People. London, Philadelphia: Kogan Page Limited.

[2] Beardwell, J; Thomson, A. (2017). Human Resource Management: A Contemporary Approach. 8th ed.. Pearson Education Limited.

[3] Boxall, P; Purcell, J; Wright, P. (2007). Boxall, P F (2007) The goals of HRM, in Oxford Handbook of Human Resource Management. Oxford: Oxford University Press.

[4] Bruce-Lockhart, A. (2020). Here's what you need to know about the future of work. Retrieved from https://www.weforum.org/agenda/2020/01/davos-2020-future-workjobs-skills-what-to-know/

[5] CBI. (2017). HELPING THE UK THRIVE - CBI/PEARSON EDUCATION AND SKILLS SURVEY. Pearson. Retrieved from 
https://www.cbi.org.uk/media/1341/helping-the-uk-to-thrive-tess2017.pdf

[6] Chatzkel, J L;. (2004). Human capital: the rules of engagement are changing, Lifelong Learning in Europe, pp 139-145.

[7] Chen, S. (2017). Higher Education Development Path Based on Practical Education Pattern. EURASIA Journal of Mathematics, Science and Technology Education. doi:DOI: 10.12973/ejmste/8076

[8] ESPAS. (2015). Global Trends to 2030: Can the EU meet the challenges ahead? ESPAS. Luxembourg: EU Pablications Office. Retrieved from https://espas.secure.europarl.europa.eu/orbis/sites/default/files/espas_fi les/about/espas-report-2015.pdf

[9] European Union. (2015). Global Trends to 2030: Can the EU meet the challenges ahead? ESPAS (European Strategy and Policy Analyses System). 2015 Reproduction is authorised provided the source is acknowledged. Luxembourg: Publications Office of the European Union.

[10] European University Association. (n.d.). Responsible Partnering Initiative and University-Business Collaborative Research. EUA - European University Association. Retrieved from https://eua.eu/101-projects/593-responsiblepartnering-initiative-and-university-business-collaborative-research.html

[11] Gray, A. (2016). The 10 skills you need to thrive in the Fourth Industrial Revolution. Retrieved from https://www.weforum.org/agenda/2016/01/the-10-skills-you-need-tothrive-in-the-fourth-industrial-revolution/

[12] Gulua, Ekaterine. (2020, March 31). TRENDS, CHALLENGES AND ORIENTATIONS OF HUMAN RESOURCE MANAGEMENT. 51-67.

[13] Gulua, E.; Kasradze, T.; Zarnadze, N. (2020, April 30). Research of Students' Attitudes toward the Management Challenges at Private and State Universities. European Journal of Social Science Education and Research Vol 7 No 1 (2020); January - April 2020; Published: Apr 30, 2020; pg., 81-98.

[14] Gulua, Ekaterine. (2013, March-April). Talent-Management - Actual Direction of Human Potential Management. "Economics and Business"International Refereed and Reviewed Scientific and Practical Journal of the Faculty of Economics and Business, Ivane Javakhishvili Tbilisi State University, N2, pp. 85-98.

[15] Gulua, Ekaterine. (2017 femol April-June). Modern Challenges of Higher Education. Economics and Business, Business and Economics Refereed and Reviewed International Scientific and Practical Journal of the Faculty of Economics and Business, Ivane Javakhishvili Tbilisi State University, Volume $\mathrm{X}, \mathrm{N} 2$, 33. 112-132.

[16] Gulua, Ekaterine. (2018, July 24). Challenges of Higher Education Learning and Scientific Research Process Management. European Journal of Multidisciplinary Studies, May-August 2018 Volume 3. Issue 3, pp. 80-100. 
[17] Gulua, Ekaterine. (2019, April 30). Management of Process and Infrastructure in Higher Education Institution. 27-46.

[18] Kasradze, T. (2018). Trends of Financing for Development in Georgia. American Scientific Journal \#21 ,32-40.

[19] Kasradze, Tea. (2013). Poverty - A Global Socio-Economic Problem. 15-18.

[20] Kasradze, Tea; Antia , Vakhtang; Gulua, Ekaterine. (2019, January - April Volume 5, Issue 1). Challenges of Financial Management of the Higher Education Institutions in Georgia. European Journal of Economics and Business Studies,, pp. 187-206.

[21] Kasradze, Tea; Zarnadze, Nino. (2018, May). Enhancing Workforce Competitiveness through Improving Quality of Education - An Indispensable Means for Overcoming Poverty. 19-21.

[22] Kasradze, Tea; Zarnadze, Nino. (2019). Challenges of Economic of Georgia: Good and Bad Economic Growth. European Journal of Economics and Business Studies, 178-186. doi:http://dx.doi.org/10.26417/ejes.v5i1.p178186

[23] Lanvin, Bruno; Monteiro, Felipe;. (2019). ThGlobal Talent Competitiveness Index. INSEAD the Adecco Group, and Tata Communications.

[24] Leaf, M. (2013). Viewpoint - The practical skill of theory. INTERNATIONAL DEVELOPMENT PLANNING REVIEW,. doi:doi:10.3828/idpr.2013.20

[25] Lezava, Diana; Amashukeli, Mariam. (2015). A study of the correspondence between the results of academic programs and the demands of the employment market in the social sciences. Tbilisi: Open Society Georgia Foundation (OSGF), Center for Social Sciences (CSS).

[26] Liu, Xiu; Chang, Shangxin. (2020). Research on the Reform of Practical Teaching of Business Administration Major in Applied Undergraduate Universities.

[27] Nelson, R R; Phelps, E S. (1966). Investment in Humans, Technological Diffusion, and Economic Growth. 56 (1/2), 69-75. New York: The American Economic Review.

[28] (\%. §.). Qualifications Frameworks (Comparative Analysis of International and National Frameworks). Ministry of Education, Science, Culture and

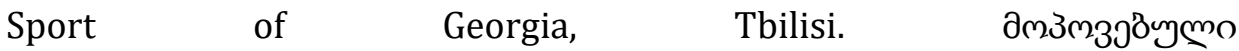
https://www.mes.gov.ge/uploads/News/kvalifikaciebis\%20charchoebi.pd $\mathrm{f}-\cos 6$

[29] Schwab, Klaus; Martín, Xavier Sala-i; Samans, Richard;. (2017-2018). The Global Competitiveness Report 2017-2018. World Economic Forum.

[30] (2007, April 13). The Lisbon Declaration. EUA, Brussels. Retrieved from http://www.aic.lv/bolona/Bologna/London_conf/Lisbon_declaration.pdf

[31] Ugochukwu Chinonso Okolie, H. E. (2019). Graduate employability: How the higher education institutions can meet the demand of the labor market. Higher Education, Skills and Work-Based Learning. doi:https://doi.org/10.1108/HESWBL-09-2018-0089 
[32] UNESCO. (2020). COVID-19 and higher education: Today and tomorrow, Impact analysis, policy responses, and recommendations. Retrieved from http://www.iesalc.unesco.org/en/wp-content/uploads/2020/04/COVID19-EN-090420-2.pdf

[33] Zarnadze, N., \& Kasradze, T. (2019). Weak Education System: The Greatest Challenge to Welfare of Society. Journal of Teaching and Education, 137-149. Retrieved from http://www.universitypublications.net/jte/0901/pdf/H9V378.pdf 